\title{
Enzymatic and genetic regulation of glycolysis in Lactobacillus delbrueckii subsp. bulgaricus
}

\author{
Gisèle Le Bras, Françoise De La Torre, Pavel Branny*, \\ Jean-Renaud Garel**
}

Laboratoire d'Enzymologie et Biochimie Structurales, CNRS, 91198 Gif-sur-Yvette, France

\begin{abstract}
In Lactobacillus bulgaricus the genes coding for phosphofructokinase and pyruvate kinase are clustered into one operon, although the reactions catalyzed by these two enzymes are seven steps apart along glycolysis. The translation of the unique messenger RNA should yield equivalent amounts of these two proteins, but their allosteric properties allow an independent control of the levels of their enzymatic activities. This enzymatic regulation involves a 'loop' in which the substrate of one enzyme is an allosteric effector of the other: fructose-6-phosphate, the substrate of phosphofructokinase, is an activator of pyruvate kinase, and phospho-enol-pyruvate, the substrate of pyruvate kinase, is an inhibitor of phosphofructokinase. Such a metabolic control, with an ante-activation by fructose-6-phosphate and a feed-back inhibition by phospho-enolpyruvate, contributes to the damping of changes in the glycolytic flux. In L. bulgaricus, the two key enzymes phosphofructokinase and pyruvate kinase are therefore coupled at the level of both their coordinated biosynthesis and the mutual control of their activities, which suggests that they are indeed involved in regulating the yield of D-lactate in fermentation. (C) Inra/Elsevier, Paris.
\end{abstract}

Lactobacillus bulgaricus / glycolysis / allosteric regulation / phosphofructokinase / pyruvate kinase

Résumé - Régulation enzymatique et génétique de la glycolyse chez Lactobacillus delbrueckii subsp. bulgaricus. Chez Lactobacillus bulgaricus, les gènes codant pour la phosphofructokinase et la pyruvate kinase sont regroupés dans un même opéron, alors que sept étapes séparent les réactions catalysées par ces deux enzymes dans la glycolyse. Les propriétés allostériques de ces deux enzymes permettent d'ajuster indépendamment leurs activités, bien que des quantités équivalentes de protéines soient produites par la traduction d'un ARN messager unique. Cette régulation enzymatique implique une « boucle » dans laquelle le substrat d'un enzyme est un effecteur allostérique de l'autre enzyme : le fructose-6-phosphate, substrat de la phosphofructokinase, est un activateur de la pyruvate kinase, et le phospho-énol-pyruvate, substrat de la pyruvate kinase, est un inhibiteur de la phosphofructokinase. Cette combinaison d'une anteactivation par le fructose-6-phosphate et d'une rétro-inhibition par le phospho-énol-pyruvate assure l'amortissement des variations du flux glycolytique. Chez L. bulgaricus, la phosphofructokinase et la pyruvate kinase sont donc couplées à la fois par une biosynthèse coordonnée et par un contrôle mutuel de leurs activités, ce qui suggère que ces deux enzymes participent effectivement à la régulation de la production de D-lactate par la glycolyse. (C) Inra/Elsevier, Paris.

Lactobacillus bulgaricus / glycolyse / régulation allostérique / phosphofructokinase / pyruvate kinase

* Present address : Microbiology-C.A.S., Videnska 1083, 14220 Prague, zech Republic.

** Correspondence and reprints 


\section{INTRODUCTION}

Lactobacillus bulgaricus (Lactobacillus delbrueckii subsp. bulgaricus ) is one of the bacteria used by the food industry for large-scale fermentation of milk into cheese and yoghurt, but despite its economic importance, little is known of its biochemistry. L. bulgaricus has a simplified catabolism: i) it can utilize only three sugars, glucose, fructose, and lactose, as carbon-energy source; ii) it is a strict fermenting bacterium which lacks a respiratory chain; and iii) its fermentation produces almost exclusively lactic acid [7]. L. bulgaricus appears then to produce most (if not all) of the energy required for its growth solely by the glycolytic breakdown of sugars.

In many cells, the flux through the glycolytic pathway is (at least in part) regulated at the level of two reactions that both involve the transfer of a phosphoryl group and are irreversible under cellular conditions. The first one is catalyzed by phosphofructokinase (PFK, EC 2. 7. 1. 11):

fructose-6-phosphate + ATP $\rightarrow$ fructose-1,6-bisphosphate + ADP,

and the other by pyruvate kinase (PYK, EC 2.7.1.40):

$$
\begin{gathered}
\text { phospho-enol-pyruvate }+ \text { ADP } \longrightarrow \\
\text { pyruvate }+ \text { ATP. }
\end{gathered}
$$

The role of PFK and PYK in controlling the rate of glycolysis is reflected in their sophisticated regulatory properties: indeed, enzymes from a variety of sources often show a co-operative saturation by one of their substrates and/or possess potent allosteric effectors [4].

We have shown earlier that the $p y k$ gene coding for PYK and the $p f k$ gene coding for PFK are adjacent on the chromosome of $L$. bulgaricus [1]. Three recent pieces of evidence led to the further conclusion that the two $p f k$ and $p y k$ genes constitute a bicistronic operon and were transcribed into a unique mRNA: i) the same mRNA with a size of $2.9 \mathrm{~kb}$ was recognized by both the $p f k$ and the $p y k$ probes; ii) a rho-independent terminator was present downstream of the $p y k$ gene and a potential promoter upstream of the $p f k$ gene; and iii) no other open reading frame was found in the vicinity of the $p f k$ or the pyk genes [2]. The same physical proximity of the pfk and pyk genes as that found in $L$. bulgaricus has also been found by DNA sequencing in other organisms such as Lactococcus lactis [10], Spiroplasma citri [3], Mycoplasma genitalium [5], Bacillus stearothermophilus [11], B. psychrophilus and B. licheniformis [12]. This proximity is however not observed in Escherichia coli where the pfkA gene coding for the major PFK is not followed by the pyk gene [6].

The clustering of several genes into a unique operon is more often observed when these genes code for 'adjacent' enzymes that catalyze consecutive reactions in a metabolic pathway. In $L$. bulgaricus for instance, the genes coding for the three enzymes that catalyze the three consecutive reactions from dihydroxyacetone-phosphate to 3-phosphoglycerate in the glycolytic pathway, glyceraldehyde3-phosphate dehydrogenase, triose-phosphate isomerase and phosphoglycerate kinase, are clustered into one tricistronic operon (unpublished results from this laboratory). The clustering into a single transcription unit of genes coding for enzymes that are not 'adjacent' along a given metabolic pathway is much less frequent. Seven steps along glycolysis separate the reactions catalyzed by PFK and PYK, and the clustering of the $p f k$ and $p y k$ genes into one operon suggests that a common transcriptional regulation might be important for controlling the rate of fermentation. A consequence of this unique transcriptional control of the expression of these genes 
is however that PFK and PYK are no longer biosynthesized independently. In absence of marked specific polar effects on the translation and/or the decay of the unique mRNA transcript of both the $p f k$ and $p y k$ genes, there will be an approximately constant ratio between the amounts of PFK and PYK chains that are biosynthesized.

The enzymatic activities of PFK and PYK must however be controlled separately to accomodate the differences in flux through the steps that they catalyze. Indeed, the flux through the PFK-catalyzed step is probably higher than that through the PYK-catalyzed step since some of the glycolytic intermediates between fructose-1,6-bisphosphate and PEP are used as precursors for the synthesis of pentose-phosphates, phospholipids, or other important compounds. Also, part of the PEP may be consumed by the phosphotransferase system instead of being used as a substrate for PYK. Therefore a fine differential adjustment of the activities of PFK and PYK is needed to allow L. bulgaricus to modulate the fluxes through the initial and final parts of its glycolytic pathway according to growth conditions.

Previous results obtained with purified PFK and PYK from L. bulgaricus have shown that PEP, the substrate of PYK, is an allosteric inhibitor of PFK [9], and that fructose-6-phosphate, the substrate of PFK, is an allosteric activator of PYK [8]. In the present work, we study quantitatively the influence of the substrate of one enzyme on the activity of the other enzyme, and we show that there is a range of fructose-6-phosphate and PEP in which PFK and PYK are coupled by a coordinated allosteric regulation.

\section{MATERIALS AND METHODS}

All materials and methods for the cloning of the $p f k$ and $p y k$ genes, the purifications and assays of PFK and PYK have been reported previously $[1,2,8,9]$. All assays of enzymatic activities were performed at $\mathrm{pH} 6$ to take into account the slightly acid intracellular $\mathrm{pH}$ of $L$. bulgaricus during fermentation.

\section{RESULTS AND DISCUSSION}

\subsection{Inhibition of PFK by PEP}

Figure 1 shows that the inhibition of PFK by PEP has the sigmoidal shape characteristic of cooperativity. This inhibition is due to a decrease in maximum velocity without any change in the affinity for either substrate fructose-6-phosphate or ATP. The inhibition is only partial since it is due to a shift in the $\mathrm{pH}$-profile of the maximum velocity [9].

\subsection{Activation of PYK by fructose-6- phosphate}

Several bacterial PYKs have been reported to be activated by fructose-1,6bisphosphate [4]. We have also observed such an activation with partially purified preparations of the enzyme from $L$. bulgaricus. This activation by fructose-1,6bisphosphate is apparent and due only to a minor contamination by a fructose-1,6bisphosphatase. It is no longer observed with homogeneous PYK. When purified, the PYK from $B$. stearothermophilus is also activated by fructose-6-phosphate and insensitive to fructose-1,6-bisphosphate [11]. Fructose-6-phosphate activates the PYK from $L$. bulgaricus by the same mechanism as do glucose-6-phosphate and ribose-5-phosphate [8], causing both an increase in apparent affinity and a decrease in cooperativity towards PEP (figure 2). This activation seems maximal at PEP concentrations around $3 \mathrm{mmol} / \mathrm{L}$, where fructose-6-phosphate enhances the acti- 


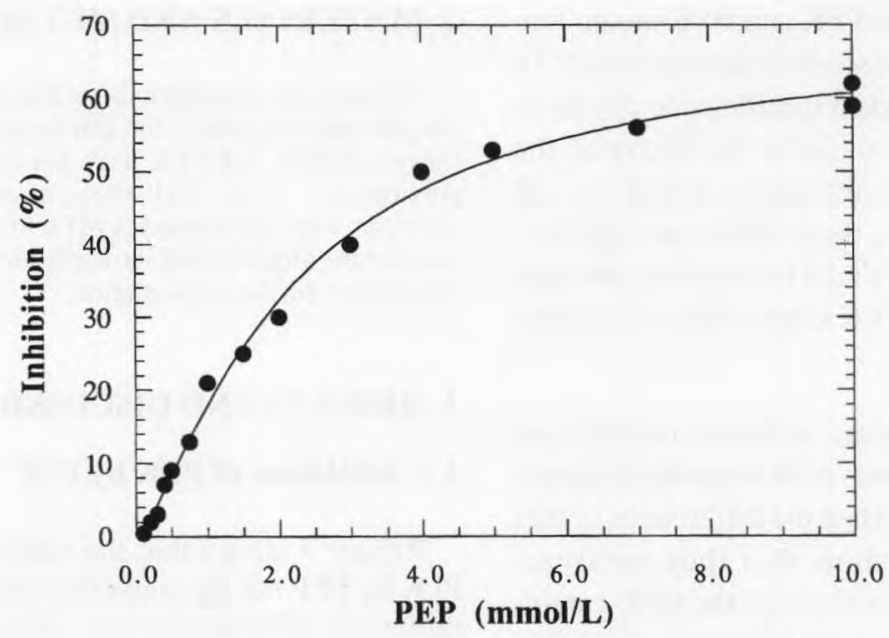

Figure 1. Inhibition of PFK by $\mathrm{PEP}$ at $\mathrm{pH}$ 6.0. Inhibition is only partial since it is related to a shift in the $\mathrm{pH}$-profile of the maximum velocity [9]. The solid curve is drawn according to the Hill equation with a maximum inhibition of $72 \%,(\mathrm{PEP})_{0.5}=2.7 \mathrm{mmol} / \mathrm{L}$, and $\mathrm{n}_{\mathrm{H}}=1.3$.

Figure 1. Inhibition de la PFK par le PEP à $\mathrm{pH}$ 6,0. L'inhibition n'est que partielle car elle résulte d'un déplacement du profil de $\mathrm{pH}$ de la vitesse maximum [9]. La courbe pleine correspond à l'équation de Hill avec un plateau d'inhibition maximum de $72 \%,(\mathrm{PEP})_{0,5}=2,7 \mathrm{mmol} / \mathrm{L}$, et $\mathrm{n}_{\mathrm{H}}=1,3$.

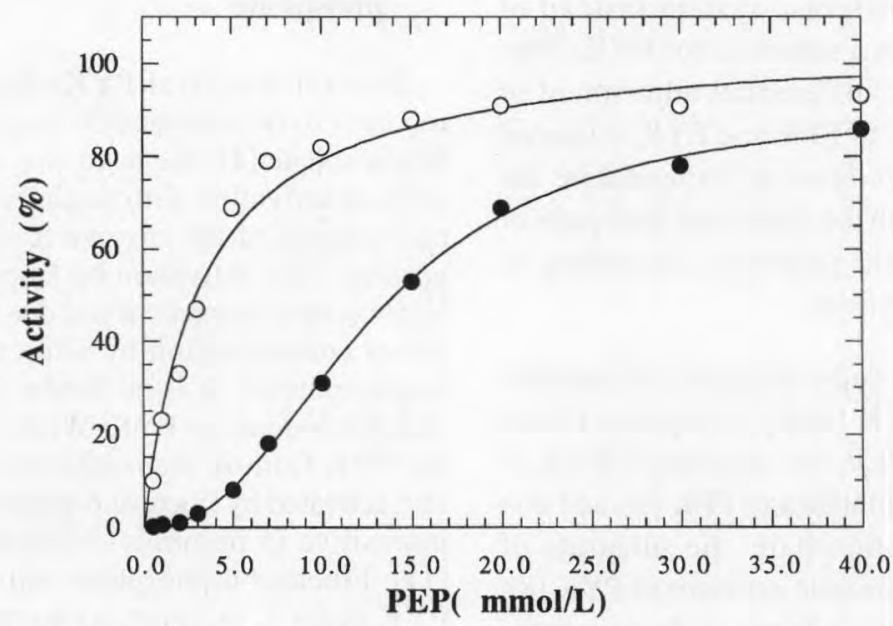

Figure 2. Saturation of PYK by PEP measured at $\mathrm{pH} 6.0$ in absence of fructose-6-phosphate (O) and in presence of $0.3 \mathrm{mmol} / \mathrm{L}$ fructose-6-phosphate $(\bigcirc)$. The solid lines correspond respectively to the Hill equation with $(\mathrm{PEP})_{0.5}=13 \mathrm{mmol} / \mathrm{L}$ and $\mathrm{n}_{\mathrm{H}}=2.4$, and the Michaelis equation with $(\mathrm{PEP})_{0.5}=3.3 \mathrm{mmol} / \mathrm{L}$.

Figure 2. Saturation de la PYK par le PEP mesurée à pH 6,0 en absence de fructose-6-phosphate $(-$ et en présence de $0,3 \mathrm{mmol} / \mathrm{L}$ fructose-6-phosphate $(\bigcirc)$. Les courbes correspondent l'une à l'équation de Hill, avec $(\mathrm{PEP})_{0,5}=13 \mathrm{mmol} / \mathrm{L}$ et $\mathrm{n}_{\mathrm{H}}=2,4$, et l'autre à l'équation de Michaelis, avec $(\mathrm{PEP})_{0,5}=3,3 \mathrm{mmol} / \mathrm{L}$. 


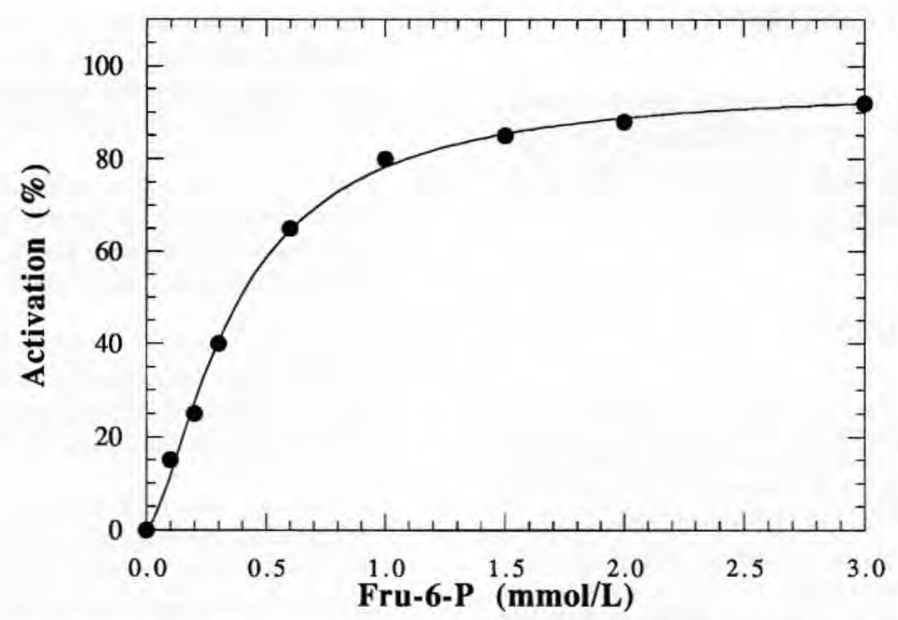

Figure 3. Activation of PYK by fructose-6-phosphate (Fru-6-P) measured at a substrate concentration of $3 \mathrm{mmol} / \mathrm{L} \mathrm{PEP}$ at $\mathrm{pH}$ 6. The solid line corresponds to the Hill equation with (Fru-6-P) 0.5 $=0.35 \mathrm{mmol} / \mathrm{L}$ and $\mathrm{n}_{\mathrm{H}}=1.5$.

Figure 3. Activation de la PYK par le fructose-6-phosphate (Fru-6-P) mesurée à une concentration en substrat de $3 \mathrm{mmol} / \mathrm{L}$ PEP et à $\mathrm{pH} 6$. La courbe pleine correspond à l'équation de Hill avec (Fru-6-P) $)_{0,5}=0,35 \mathrm{mmol} / \mathrm{L}$ et $\mathrm{n}_{\mathrm{H}}=1,5$.

vity from a very low level to a significant value. Figure 3 gives the increase with fructose-6-phosphate of the activity assayed at $3 \mathrm{mmol} / \mathrm{L}$ PEP and shows that a fructose-6-phosphate concentration of about $0.3 \mathrm{mmol} / \mathrm{L}$ causes half the maximal activation.

\subsection{Comparable concentrations of PEP and fructose-6-phosphate are both half-saturating for one enzyme and allosterically half-effective towards the other enzyme}

A concentration of fructose-6-phosphate of $0.3 \mathrm{mmol} / \mathrm{L}$ causes half the maximal activation of PYK when measured at $3 \mathrm{mmol} / \mathrm{L} \mathrm{PEP}$ (figure 3). This value of $0.3 \mathrm{mmol} / \mathrm{L}$ is the same as that of the concentration of fructose-6-phosphate required for half-saturation of PFK in the same conditions [9]. Similarly, (about) the same PEP concentration around $3 \mathrm{mmol} / \mathrm{L}$ corresponds to both the half-maximal inhibition of PFK (figure 1) and the half-saturation of PYK in the presence of 0.3 $\mathrm{mmol} / \mathrm{L}$ fructose-6-phosphate (figure 2). Therefore, at $0.3 \mathrm{mmol} / \mathrm{L}$ fructose- 6 -phosphate and $3 \mathrm{mmol} / \mathrm{L}$ PEP, the two key enzymes will be both at half saturation and at half allosteric effect.

The conclusion of this work is thus that, in L. bulgaricus, the allosteric properties of two key enzymes PFK and PYK are such that their activities are not independent of each other. They are coupled by a regulation 'loop' in which the substrate of one enzyme is an allosteric effector of the other. This coordinated regulation implies both the retro-inhibition of a terminal enzyme and the ante-activation of an initial enzyme, and this pairing probably contributes to the stability of the glycolytic steady-state upon variations of sugar input. 


\section{ACKNOWLEDGMENTS}

This work has been supported by grants from the C.N.R.S. (U.P.R.9063), the Université Pierre-et-Marie Curie (9270300), and by the Danone group.

\section{REFERENCES}

[1] Branny P., de la Torre F., Garel J.R., Cloning, sequencing, and expression in Escherichia coli of the gene coding for phosphofructokinase in Lactobacillus bulgaricus, J. Bacteriol. 175 (1993) 5344-5349.

[2] Branny P., de la Torre F., Garel J.R., The genes for phosphofructokinase and pyruvate kinase of Lactobacillus delbrueckii subsp. bulgaricus constitute an operon, J. Bacteriol. 178 (1996) 4727-4730.

[3] Chevalier C., Saillard C., Bové J., Organization and nucleotide sequences of the Spiroplasma citri genes for ribosomal protein S2, elongation factor Ts, spiralin, phosphofructokinase, pyruvate kinase, and an unidentified protein., J. Bacteriol. 172 (1990) 2693-2703.

[4] Fothergill-Gilmore L.A., Michels P.A.M. Evolution of glycolysis, Prog. Biophys. Mol. Biol. 59 (1993) 105-235.

[5] Fraser C.M., Gocayne J.D., White O., Adams M.D., Clayton R.A., Fleischmann R.D., Bult C.J., Kerlavage A.R., Sutton G., Kelley J.M., Fritschman J.L., Weidman J.F., Small K.V., Sansusky M., Fuhrman J., Nguyen D., Utterback T.R., Saudek D.M., Phillips C.A., Merrick J.M., Tomb J.F., Dougherty B.A., Bott K.F., Hu P.C., Lucier T.S., Peterson S.N., Smith H.O., Hutchison III C.A, Venter J.C., The minimal gene complement of Mycoplasma genitalium, Science 270 (1995) $397-403$.
[6] Hellinga H.W., Evans P.R., Nucleotide sequence and high-level expression of the major Escherichia coli phosphofructokinase, Eur. J. Biochem. 149 (1985) 363-373.

[7] Kandler O., Weiss N., Regular, nonsporing Gram-positive rods, in: Bergey's manual of systematic bacteriology, Vol. 2, Williams, Wilkins, Baltimore, U.S.A. (1986) 1208-1234 .

[8] Le Bras G., Garel J.R., Pyruvate kinase from Lactobacillus bulgaricus: possible regulation by competition between strong and weak effectors, Biochimie 75 (1993) 797-802.

[9] Le Bras G., Deville-Bonne D., Garel J.R., Purification and properties of the phosphofructokinase from Lactobacillus bulgaricus: a non-allosteric analog of the enzyme from Escherichia coli, Eur. J. Biochem. 198 (1991) 683-687.

[10] Llanos R.M., Harris C.J., Hillier A.J., Davidson B.E., Identification of a novel operon in Lactococcus lactis encoding three enzymes for lactic acid synthesis: phosphofructokinase, pyruvate kinase, and lactate dehydrogenase, J. Bacteriol. 175 (1993) 2541-2551.

[11] Sakai H., Ohta T., Molecular cloning and nucleotide sequence of the gene for pyruvate kinase of Bacillus stearothermophilus and the production of the enzyme in Escherichia coli, Eur. J. Biochem. 211 (1993) 851-859.

[12] Tanaka K., Sakai H., Ohta T., Matsuzawa H., Molecular cloning of the genes for pyruvate kinases of two bacilli, Bacillus psychrophilus and Bacillus licheniformis, and comparison of the properties of the enzymes produced in Escherichia coli, Biosci. Biotech. Biochem. 59 (1995) 1536-1542. 